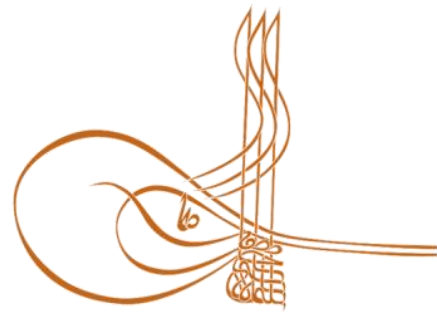

www.turkishstudies.net/religion
Turkish Studies - Comparative Religious Studies

eISSN: $2667-5544$

Research Article / Araştırma Makalesi

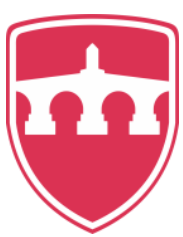

INTERNATIONAL BALKAN

UNIVERSITY

Sponsored by IBU

\title{
Etvâr-ı Seb'a Geleneği ve Vâhib Ümmî’de Etvâr-ı Seb‘a
}

\author{
Atwar-ı Sab'a Tradition and Atwar-ı Sab'a in the Collection of Vahib Ummi
}

\author{
Mehmet Şahin**
}

\begin{abstract}
The subject of our study is to examine atwar-1 saba, to determine prose and verse works written in this subject, to draw the general framework and to determine the seven manners of the self by means of Vahib Ummi's collection (Divan-1 İlahiyyat). 56 verses and prose works written on atwar-1 saba were identified and their places in the library were shown as a result of this study designed with archival research method. According to the initial findings, most of the works were not subject to academic examination. It was observed that 56 works found about atwar-1 saba were mainly written by members of the Khalwatiyyah dervish order. Atwar-1 saba refers to the seven manners of self, consisting of commanding self (emmare), accusing self (levvame), inspiring self (mülhime), serene self self (mutmainne), pleased self (raziye), fulfilling self (marziyye) and purified \& complete self (kamile). Each stage has a place and each place has an invocation. The place of commanding selfis head, place of accusing self is heart, place of inspiring self is soul, place of serene is secret, place of pleased self is hint, place of fulfilling self is holy wisdom and place of purified \&complete self is the most hidden secret (ahfa). Exceeding these levels is known as sayr-u suluk and in each stage, a name of Allah is mentioned. By mentioning La ilahe illallah (There is no God but Allah) in commanding self, Allah (God) in accusing self, Hu in inspiring self, Haqq in serene self, Hayy in pleased self, Qayyoom in fulfiling self and Qahhar in purified \&complete self, daily invocations are made. In this study, after these issues were revealed, they were determined in the collection (Divan-1 İlahiyyât) of Vahib Ummi. Based on Divan, it is seen that Vahib Ummi considered atwar-1 saba as a part of the course on the way to become a perfect human being. The poets about atwar-1 saba were revealed and their short introductions were made.
\end{abstract}

Structured Abstract: Atwar-1 saba, which is used as a mystical term to express each of the degrees of the human self, means seven manners. These seven manners and places are as follows: the first manner is commanding self (emmare) whose place is head. The second manner is accusing self (levvame) whose place

\footnotetext{
* Bu makale, 12-14 Ekim 2018 tarihleri arasında Akdeniz Üniversitesi’nde düzenlenen "Turkish Academic Research Review International Multidisciplinary Congress"'te sunulan bildirinin içerik ve kaynakça açısından gözden geçirilip genişletilmiş halidir.

This article is an extended version of the paper, presented at Turkish Academic Research Review International Multidisciplinary Congress held on 12-14 October at Akdeniz University, in terms of content and references.

** Dr. Öğr. Üyesi, Akdeniz Üniversitesi/İlahiyat Fakültesi/Türk-İslam Edebiyatı

Asst, Prof. Dr., Akdeniz University, Faculty of Theology, Turkish-İslamic Literature

ORCID 0000-0002-2548-211X

mehmetsahin@akdeniz.edu.tr

Cite as/ Atıf: Şahin, M. (2020). Etvâr-1 Seb'a geleneği ve Vâhib Ümmî’de Etvâr-1 Seb‘a, Turkish Studies - Religion, 15(1), 77-96. https://dx.doi.org/10.29228/TurkishStudies.40030

Received/Geliş: 05 December/Aralık 2019

Accepted/Kabul: 25 March/Mart 2020

Checked by plagiarism software

Copyright (C) INTAC LTD, Turkey 
is the heart. The third manner is inspiring self (mülhime) whose place is the soul. The fourth manner is serene self (mutmainne) whose place is secret. The fifth manner is pleased self (raziye) whose place is hint. The sixth manner is fulfilling self (marziyye) whose place is holy wisdom. The seventh manner is purified \& complete self (kamile) whose place is the most hidden secret. Fifty-six works on this subject that have been found so far have been written. The fact that so many works have been written emphasizes the importance of the subject, and it is also remarkable in terms of showing that it has a response by the public. The authors and works writing on the subject are as follows: Muhyiddin İbnü'l-Arabî (d. 638/1240) - Risâle fî Etvâri't-Tasavvuf/et-Tasavvuf et-Tusâî, Abdülkerim el-Cîlî (d. 832/1428) - Risâle fî̀ Etvârı Seb'a, Abdullatif Makdisî (d. 856/1452) - etTuhfetu'l-Vâhibü'l-Mevâhib, Akşemseddin Mehmed b. Hamza (d.864/1456) - Ahvâlü's-Sülûk, Yahya Şirvânî (d. 869/1464) - Etvâr-1 Kulûb, Yahya Şirvânî (d. 869/1464) - Şerh-i Merâtib-i Etvâr-1 Kulûb, Mevlânâ Pir Muhammed el-Erzincânî (d.879/1474) - Atwar-1 Saba, Habib Ömer el-Halvetî (d. 902/1497) - Manzûme fî Etvâri’s-Seb'a, Seyyid İbrahim Efendi (d.935/1528) - Atwar-1 Saba, İbrahim Gülșenî (d.940/1533) - Atwar-1 Saba, Abdullah b. Abdulaziz el-Uşşâkî (d.1197/1783) - Atwar-1 Saba, Abdullah b. Abdulaziz el-Uşşâkî (d.1197/1783) - Mirât-1 Esmâ, Halilî-i Maraşî (d.998/1589) - Atwar-1 Saba, Seyyid Nizamoğlu Seyfullah (d.1010/1602) - Atwar-1 Saba, Kuloğlu Mustafa (d.1045/1635) - Manzûm Atwar-1 Saba, Gülaboğlu Mehmed Kütahyalı Askerî (d. 1104/1693) - Dîvân, Cemaleddin Muhammed b. Mahmud Aksarâyî (d.903/1497) Etvâru'l-Kulûb, Cemaleddin Muhammed b. Mahmud Aksarâyî (d.903/1497) - Risâletü'l-Etvâr, Cemaleddin Muhammed b. Mahmud Aksarâyî (d.903/1497) - Risâle fî Etvâri's- Seb'a, Cemaleddin Muhammed b. Mahmud Aksarâyî (d.903/1497) - Risâle fi'l-Etvâr ve'l-Merâtib, Yiğitbaş Ahmed Şemseddin Marmaravî (d.910/1505) - Atwar-1 Saba, Cemâleddin İshak Karamânî (d. 933/1527) - Risâle fî̀ Etvâri's-Sülûk, Cemâleddin İshak Karamânî (d. 933/1527) - Risâle fî Etvâri's- Seb‘a, Yusuf Sinan b. Ali (d. 936/1529) Risâletü'l-Etvâri's- Seb'a, Seyfullah Kâsım b. Nizâmeddin (d.1010/1601) - el-Atvâru's-Seb'a fî̀ Tarîki'sSûfiyye, Şah Veli b. Muhammed b. Kaya Nâib el-Aksarayî (d. 1013/1605) - Risâle fî Etvâri's-Seb'a, Muhammed b. Halife (d. 1020/1611) - Etvâru’s- Seb'a, Şeyhülislam Kemalpaşazâde (d. 940/1534) - Risâle-i Nefs, Bâlî Efendî Sofyavî (d.960/1553) - Risâle-i Atwar-1 Saba, Şücaeddin İlyas b. İsa b. Mecdüddin esSaruhanî Akhisârî (d. 967/1559) - Risâle-i Atwar-1 Saba, Şeyh Mustafa b. Seyyid Ali Akşehrî (d.972/1564) Risâle, Lâ Mekânî Hüseyin Efendi (d.1034/1624) - Risâle fî̀ Atvâri's-Seb'a fi's-Sülûk, Seyyid İsmail Bedreddin (d. 1292/1875-6) - Etvâr-1 Seb'a Risâlesi, Mehmed Emin Tokadî (d.1158/1745) - Etvâr-1 Makâmât1 Hazret-i Ali, Anonymous- Etvâr-1 Sülûk-i Kadiriyye, Ayntâbî Muhammed Emin b. Muhammed Esad'ın (d. 19 century) - Ezvâkü'l-Hâlîdî ve Etvârü'n-Nakşbendî, Mustafa b. Yusuf Nizameddin (d.1187/1783) - Etvâr-1 Melâmetiye, Azîz Mahmud Hüdâyî (d. 1038/1628) - Risâle-i Atwar-1 Saba, Abdulgaffar b. Ramazan (ö.17. yy) - Risâle-i Atwar-1 Saba, Kemâleddin el-Harîrî (d.1299/1882) - Risâle-i Ta'bîr-i Vâkı'ât, Anonymous Etvâr-1 Sûfiyye, Şeyh Ömer Fuâdî (d. 1046/1636-7)- Beyân-1 Atwar-1 Saba, Hasan Ünsî Efendi (d. 1136/1723) - Etvâr-1 Seb'a, Muhammed b. Ali el-Malatî (d. 1105/1693) - Atwar-1 Saba, Cemâleddin Edirnevî Uşşakî (d. 1164/1751) - Risâle fî Beyâni Etvâr-1 Sülûk ve Ba'zı Makâmât, La'lî el-Fenâyî el-Gülşenî (d. 1112/1701) Atwar-1 Saba, Ahmed Müsellim Efendi (d.1166/1752) - Şerh-i Kasîde-i Şümûun Lâmî‘ fî̀ Beyân-1 Atvâr-1 Seb'a, Hilmi b. Muhammed Tâhir - A story about Sufism (Tasavvufa Dair Bir Risâle), İbrahim Hakkı Erzurûmî (d.1186/1772) - Atvâr-1 Seb ‘a, Mehmed Şâkir Efendi (d. 1269/1852) - Atwar-1 Saba Risâlesi, İbrahim - Risâlei Etvâr-1 Seb'a, Anonymous - Nüfûs u Seb'a, Ahmed Müsellem Ebu'l-Vefâ Edirnevî (d. 1168/1754) - Şerh-i Kasîde-i Şumûu'l-Lâmî fî Beyâni Atwar-1 Saba, Anonymous - Atvâr-1 Seb'a, Anonymous - Atvâr-1 Seb'a Risâlesi, Seyyid Ahmed Cezbî - Kenzü'l-Etvâr

Vahib Ummi reviewed atwar-1 saba in his divan as a process in terms of education and development. He emphasized in many poems that the saliks (members of a cult) who followed this process could be a perfect human being. He expressed the stages of the person passing through the levels of the self to know himself first and then the God in a lyrical language and a metaphorical style. His style is simple and understandable, like the style of the poet Yunus Emre.

Since the sect was not in a close relationship with the public, he reduced the mystical intricate subjects to the level that the public can understand and used the atwar-1 saba as an education system to educate the public. The didactic aspect of his poems reveals it clearly.

According to Vahib Ummi, chatting and continuous invocation is certainly required for reaching the target. Those who do not clean their self and cannot pass seven manners and stages, cannot finish his journey. For this reason, he wrote many poems, which we gave examples above, with a decent style to present the obstacles to be encountered, to show the way and to cover the distances in a short way for completing the final rank of the self on the way to become a perfect human being. 
Such religious texts of Sufism are of great importance in terms of religious literature. Many works have been written in Sufism literature about atwar-1 saba, both poetic and prose, both as a detached and as a chapter in the book. The framework of the works and the subjects are clear. In this regard, the subject of atwar1 saba was also addressed by divan poets.

Vahib Ummi built his Sufi education on the relationship between body, self and spirit. He dealt with Atwar-1 Saba both theoretically and practically. Vahib Ummi, who developed a special method for each of the seven manners, used a special, different name of God in each manner. He also said that these names will differ according to the condition of the salik. The person who completes his journey knows himself first, and the person who knows himself knows God. The one who knows his God reaches true ingenuity and secret. The salik, who completed the seven manners, could get rid of his self, moralize his character, leave the world for God and become a divine manifestation. He abandoned the duality and reached true dissent.

Keywords: Atwar-1 saba, Vahib Ummi, Khalwatiyya, Seven manners, Stages of self.

Öz: Çalışmamızın konusu etvâr-1 seb'a'nın incelenmesi, yazılan mensur ve manzum eserlerin tespit edilmesi, genel çerçevesinin çizilmesi ve Vâhib Ümmî'nin Dîvân-1 İlâhiyyat'ından hareketle nefsin yedi tavrının tespitidir. Arşiv araştırması yöntemiyle hazırlanan bu çalışma neticesinde etvâr-1 seb'a konusunda yazılmış 56 adet manzum ve mensur eser tespit edilerek, kütüphanedeki yerleri gösterilmiştir. İlk tespitlere göre, eserler büyük oranda akademik olarak incelemeye tabi tutulmamıştır. Etvâr-1 seb’a hakkındaki tespit edilen 56 eserin çoğunun Halvetiyye tarikati mensuplarınca yazıldığı görülmüştür. Etvâr-1 Seb'a: nefs-i emmâre, nefs-i levvâme, nefs-i mülhime, nefs-i mutmainne, nefs-i raziyye, nefs-i marziyye ve nefs-i kâmile olarak yedi mertebenin adıdır. Her mertebenin bir makamı, her makamın da bir zikri bulunmaktadır. Emmârenin makamı sadr, levvâmenin makamı kalp, mülhimenin makamı ruh, mutmainnenin makamı sır, raziyenin makamı hafî, marziyyenin makamı kürsî, kâmilenin makamı ise ahfâ'dır. Bu mertebelerin aşılması seyr ü sülük olarak bilinir ki her bir mertebede Allah'ın bir ismi zikredilir. Emmârede Lâ ilâhe illallah, levvâmede Allah, mülhimede Hû, mutmainnede Hak, râziyede Hay, marziyyede Kayyûm ve kâmilede ise Kahhâr ismi zikredilerek günlük virdler yapılır. Bu çalışmada bunlar ortaya konulduktan sonra Vâhib Ümmî'nin Dîvân-1 İlâhiyyât'ında bunların tespiti yapılmıştır. Dîvân'dan hareketle Vâhib Ümmî’nin etvâr-1 seb‘ayı insan-1 kâmil olma yolunda seyr ü sülûkun bir parçası olarak ele aldığı görülmüştür. Etvâr-1 seb`a ile ilgili manzumeler tespit edililerek kısa tanıtımları yapılmıştır.

Anahtar Kelimeler: Etvâr-1 seb’a, Vâhib Ümmî, Halvetiyye, Yedi tavır, Nefsin mertebeleri.

\section{Giriş}

Etvâr-1 Seb ‘a, tasavvufta insanın nefsini terbiye ederek ruhunu olgunlaştırması, seyr ü sülûku ve insân-1 kâmil olma yolunda eğitim aşamalarını ifade etmek için kullanılan bir kavramdır. Tavr kelimesinin çoğulu olan etvâr; tavırlar, davranışlar, haller, hareketler ve sınır anlamlarına gelmektedir. (İbn Manzur 1985:507-508; el-Firûzâbâdî ts.: 501502; Ahterî 1283: 15; Çağbayır 2007: 1512; Şemseddin Sami 1996: 894; Redhouse 1992: 1252) Etvâr-1 Seb'a ise yedi tavir, insan nefsinin yedi derecesinden her birini ifade etmek için kullanılan tasavvufî bir terimdir. (Çağbayır 2007: 1512) Etvâr-1 Seb`a konusunda eser veren müelliflere göre ise bu yedi merhalelerin isimleri şunlardır: 1. Seyr ila'1lâh 2. Seyr li'1lâh, 3. Seyr al'1lâh, 4. Seyr maa'llâh, 5. Seyr fi'llâh, 6. Seyr ani'1lâh, 7. Seyr bi’llâh. (Usta 2015: 56) Tasavvuf literatüründe büyük bir yer kaplayan etvâr-1 seb'a farklı açılardan da ele alınmaktadır. En yaygın kullanım şekillerinden biri olan hâl açısından ele alındığında ise nefsin derecesine göre değişen hallerin her birine denilmektedir ki onlar da şunlardır: tab', nefs, kalb, ruh, sir, hafî, ahfâ. (Cebecioğlu 2014: 152) Nefs mertebelerinin sayıs1, ilk dönemlerden itibaren makam sayısına göre değişiklik arz etmiştir. Mesela Gazâlî, Atâullah İskenderî, Râgıb el-Isfahânî, Necmeddin-i Kübrâ ve Şihâbüddin Sühreverdî gibi mutasavvıflar üçlü (emmâre, levvâme, mutmainne); Hakîm-i Tirmizî ve Eşrefoğlu Rûmî gibi mutasavvıflar dörtlü (emmâre, levvâme, mülhime, mutmainne); Osmanlı mutasavvıfları ise genellikle yedili tasnifi (emmâre, levvâme, mülhime, mutmainne, râziye, marziye, kâmile) benimsemișlerdir. (Bostanc1 1996: 18; Muslu 2007: 44) "Bu süreç esnasında sûfî hakikati itibariyle kendi benliğinden ibaret olan zâtına/kalbine/nefsine 
doğru bir yolculukta bulunmaktadır. Bu yolculuk esnasındaki merhaleler/mertebeler/makamlar farklı isimlerle anılmış olsa bile aynı hakikati ifade etmektedir." (Usta 2015: 109) Aşağıdaki liste bu hususu göstermektedir.

\section{Etvâr-1 Seb’a}

1. İlk Tavr: Nefs-i emmâre, seyr il'lallah, makamı sadr.

2. İkinci Tavr: Nefs-i levvâme, seyr ale'llah, makamı kalb.

3. Üçüncü Tavr: Nefs-i mülhime, seyr bi'llah, makamı ruh.

4. Dördüncü Tavr: Nefs-i mutmainne, sey ani'llah, makamı sırr.

5. Beşinci Tavr: Nefs-i Râziye, seyr fi'llah, makamı sırru's-sır.

6. Altıncı Tavr: Nefs-i Marziyye, seyf maa'llah, makamı hafî.

7. Yedinci Tavr: Nefs-i Kâmile, seyr al'llah, makamı ahfâ.

Etvâr-1 seb'a kavramının "Görmediniz mi Allah yedi gögü, tabaka tabaka nasıl yaratmıştır?” (Nûh 71:14) ayetinden mülhem olarak terim anlamı kazandığ ifade edilmektedir. (Uludağ 1991: 65) Başta Halvetîlik olmak üzere tarîkatların çoğu tarafından etvâr-1 seb'a ile ilgili bir çok eserin kaleme alınmış olması bir geleneğin varlığına delalet etmektedir. Konuyla ilgili müstakil eserler olduğu gibi farklı eserlerin içerisinde bir bölüm olarak da yazılmıştır. Etvâr-1 seb'a, bir çok araştırmacının ilgisini çekerek bilimsel çalışmalara konu edinilmiştir. Bali Efendi'nin kaleme aldığı Etvar-ı Seb'a Risalesi bu alanda yazılmış en kapsamlı eserlerden biridir. Bu eser hem Erhan Bostancı hem de Ali Haydar Bostancı tarafından yüksek lisans tezi olarak çalışılmıştır. Fatma Şengül, Uşş̧akilerde Etvâr-ı Seb'a adlı yüksek lisans tezi ile Uşşakilik mezhebinin konuya yaklaşımını incelemiştir. Muhiddin Usta ise Tasavvuf Eğitiminde Etvâr-ı Seb'a Metodu isimli doktora tezi hazırlamıştır. Fatih Küçüktiryaki, XVI ve XVII. Yüzylllarda Osmanl Toplumunda Yazılan Atvâr-l Seb'a Eserlerinin Mukayeseli Değerlendirilmesi ve Cemile Sağır, Şah Velî Ayntâbî'nin Atvâr-ı Seb'a Risalesi (Metin-tahlil) konulu yüksek lisans tezleri hazırlamışlardır. Bu alanda telif edilen eserlerden tespit edilebilenler ise şunlardır:

Tasavvuf et-Tusâî ${ }^{1}$

1. Muhyiddin İbnü'l-Arabî (ö. 638/1240) - Risâle fî̀ Etvâri’t-Tasavvuf/et-

2. Abdülkerim el-Cîlî (ö. 832/1428) - Risâle fî Etvârı Seb 'a

3. Abdullatif Makdisî (ö. 856/1452) - et-Tuhfetu'l-Vâhibü'l-Mevâhib ${ }^{3}$

4. Akşemseddin Mehmed b. Hamza (ö.864/1456) - Ahvâlü's-Sülûk ${ }^{4}$

5. Yahya Şirvânî (ö. 869/1464) - Etvâr-1 Kulûb

6. Yahya Şirvânî (ö. 869/1464) - Şerh-i Merâtib-i Etvâr-1 Kulûb ${ }^{6}$

\footnotetext{
${ }^{1}$ İbnü'l-Arabî, Risale fi Etvâri't-Tasavvuf (et-Tasavvufu't-tüsâî), Süleymaniye Ktp., Bağdatlı Vehbi, nr. 704/2, vr. 40b66 .

${ }^{2}$ Abdülkerim el-Cîlî, Risâle fî Etvâr-ı Seb'a, Süleymaniye Ktp., Yazma Bağışlar, nr. 2998/14, vr. 92b-93a (182-183).

${ }^{3}$ Abdüllatif Makdîsî, et-Tuhfetu'l-Vâhibü'l-Mevâhib, Süleymaniye Ktp., Cârullah, nr. 2061/49, vr. 187b-193a; Orhan Kaymak, Abdüllatif el-Makdisi'nin Hayatı ve Tuhfetü Vâhibi 'l-Mevahib fî Beyâni'l-Makamât ve'l-Merâtib adlı eserinin tahkiki, Yüksek Lisans Tezi, Marmara Ünviversitesi, Sosyal Bilimler Enstitüsü, İstanbul 1992.

${ }^{4}$ Akşemseddin, Ahvâlu's-Sülûk, Süleymaniye Ktp., Tahir Ağa Tekkesi, nr. 334 vr. 84a-85a.

${ }^{5}$ Yahya Şirvânî, Etvâru'l-Kulûb, Süleymaniye Ktp., Hacı Mahmut Ef., nr. 2613/6, vr. 88a-103a; a. mlf., Etvâru'l-Kulûb, Süleymaniye Ktp., Nurosmaniye, nr. 4904/8, vr. 28b-32b; a.mlf., Etvâru'l-Kulûb, Muğla Hoca Mustafa Ktp., nr. 183/6, vr. 97b-111a.

${ }^{6}$ Yahya Şirvânî, Şerh-i Merâtibu Etvâru'l-Kulûb, Süleymaniye Ktp., Hac1 Mahmut Ef., nr. 2613/5, vr. 72a-88a; a.mlf., Risâle fî̀ Etvâri Seb'a, Süleymaniye Ktp., Esad Ef., nr. 1663/2, vr. 21b- 31b.
} 
7. Mevlânâ Pir Muhammed el-Erzincânî (ö.879/1474) - Etvâr-1 Seb 'a ${ }^{7}$

8. Habib Ömer el-Halvetî (ö. 902/1497) - Manzûme fî Etvâri’s-Seb ‘a ${ }^{8}$

9. Seyyid İbrahim Efendi (ö.935/1528) - Etvâr-1 Seb ‘ $\mathrm{a}^{9}$

10. İbrahim Gülşenî (ö.940/1533) - Etvâr-1 Seb`a ${ }^{10}$

11. Abdullah b. Abdulaziz el-Uşşâkî (ö.1197/1783) - Etvâr-1 Seb 'a ${ }^{11}$

12. Abdullah b. Abdulaziz el-Uşşâkî (ö.1197/1783) - Mirât-1 Esmâ ${ }^{12}$

13. Halilî-i Maraşî (ö.998/1589) - Etvâr-1 Seb'a ${ }^{13}$

14. Seyyid Nizamoğlu Seyfullah (1010/1602) - Etvâr-1 Seb'a ${ }^{14}$

15. Kuloğlu Mustafa (ö.1045/1635) - Manzûm Etvâr-1 Seb'a ${ }^{15}$

16. Gülaboğlu Mehmed Kütahyalı Askerî (ö. 1104/1693) - Dîvân ${ }^{16}$

17. Cemaleddin Muhammed b. Mahmud Aksarâyî (ö.903/1497) - Etvâru'l-Kulûb ${ }^{17}$ Etvâr ${ }^{18}$

18. Cemaleddin Muhammed b. Mahmud Aksarâyî (ö.903/1497) - Risâletü'l-

19. Cemaleddin Muhammed b. Mahmud Aksarâyî (ö.903/1497) - Risâle fî Etvâri’s- Seb'a ${ }^{19}$

20. Cemaleddin Muhammed b. Mahmud Aksarâyî (ö.903/1497) - Risâle fi'l-Etvâr ve'l-Merâtib $^{20}$

21. Yiğitbaş Ahmed Şemseddin Marmaravî (ö.910/1505) - Etvâr-1 Seb ‘a ${ }^{21}$

22. Cemâleddin İshak Karamânî (ö. 933/1527) - Risâle fî̀ Etvâri’s-Sülûk ${ }^{22}$

23. Cemâleddin İshak Karamânî (ö. 933/1527) - Risâle fî̀ Etvâri’s- Seb‘a ${ }^{23}$

24. Yusuf Sinan b. Ali (ö. 936/1529) - Risâletü'l-Etvâri’s- Seb ‘a ${ }^{24}$

\footnotetext{
${ }^{7}$ Mevlânâ Pir Muhammed el-Erzincânî, Marmara Üniversitesi İlahiyat Fakültesi Ktp., Genel, no:15966, vr. 17.

${ }^{8}$ Habib Ömer el-Halvetî, Manzume fì Etvari's-Seb'a, Süleymaniye Ktp., Esad Ef., nr. 1321, vr. 1b-51a.

${ }^{9}$ Seyyid İbrahim Efendi, Atvâr-l Seb 'a, Süleymaniye Ktp., Tâhir Ağa, no: 334, vr. 3.

${ }^{10}$ İbrahim Gülşenî, Etvâr-ı Seb ‘ $a$, Millî Ktp., Yazmalar, nr. 2482/6, vr. 88b-99b.

${ }^{11}$ Selahaddin Abdullah b. Abdülaziz el-Uşşakî, Etvâr-ı Seb ‘a, Süleymaniye Ktp., Tahir Ağa Tekkesi, nr. 503/2, vr. 10a13a.

${ }^{12}$ Salahaddin Uşşâkî, Mir'âtü 'l-esmâ, İBB. Atatürk Kitaplı̆̆ı Nadir Eserler Ktp., Osman Ergin Yazmaları, nr. 1501/03, vr. $12 \mathrm{~b}-22 \mathrm{a}$.

${ }^{13}$ Halilî-i Maraşî, Etvâr-ı Seb 'a, Süleymaniye Ktp., Şehid Ali Paşa, nr. 1121/1, vr. 10a-13a; Halîlî-i Maraşî, Divançe ve Etvâr-ı Seb`a, haz. Lütfi Alıcı, Ukde Yayınevi, Kahramanmaraş 2010.

${ }^{14}$ Seyyid Nizamoğlu Seyfullah, Etvâr-ı Seb ‘a, Yahya Efendi Matbaas1, İstanbul, 1288, s. 28-34.

${ }^{15}$ Kuloğlu Mustafa, Manzum Etvâr-l Seb ‘a, Süleymaniye Ktp., nr. 1003/22, vr. 346b-388b.

${ }^{16}$ Gülaboğlu Mehmed Kütahyalı Askerî, Divan, İBB. Atatürk Kitaplığı Nadir Eserler Ktp., Osman Ergin Yazmaları, nr. 337.

${ }^{17}$ Çelebi Halîfe, Etvaru'l-Kulûb, Süleymaniye Ktp., Hekimoğlu, nr. 438/2, vr. 41a-45b.

18 Çelebi Halîfe, Risâletü'l-Etvâr, Ankara Adnan Ötüken İl Halk Ktp., nr. 4754, vr. 199b-202a.

${ }^{19}$ Çelebi Halîfe, Risâle fí Etvâri's-Seb'a, Millî Ktp., Yazmalar, nr. 2196/2, vr. 7b-17b.

${ }^{20}$ Çelebi Halîfe, Risale fi'l-Etvar ve'l-Meratib, Süleymaniye Ktp., Hekimoğlu, nr. 438/3, vr. 47a-52a.

${ }^{21}$ Yiğitbaş Ahmed Şemseddin Marmaravî, Etvar-l Seb'a, Süleymaniye Ktp., Hacı Mahmut Ef., nr. 2688/5, vr. 59a-68b; Ahmet Ögke, Ahmed Şemseddin Marmaravî, Hayatı, Eserleri, Görüşleri, II. Baskı, İnsan Yayınları, İstanbul 2006, s. 55070.

${ }^{22}$ Cemâleddin İshak Karamânî, Risâle fí Etvâri's-Sülûk, Millî Ktp., Yazmalar, nr. 9007/13, vr. 123b-127a.

${ }^{23}$ Cemâleddin İshak Karamânî, Risale fì Etvâri 's-Seb 'a, Süleymaniye Ktp., Şehid Ali Paşa, nr. 1194/2, vr. 21b-26b.

${ }^{24}$ Sünbül Sinan, Risaletü’l-Etvari's-Seb ‘a, İBB. Atatürk Kitaplığı Nadir Eserler Ktp., Osman Ergin Yazmaları, nr. 341/02, vr. 23b-24a.
} 

Sûfiyye $^{25}$

25. Seyfullah Kâsım b. Nizâmeddin (ö.1010/1601) - el-Atvâru's-Seb'a fî̀ Tarîki's-

26. Şah Veli b. Muhammed b. Kaya Nâib el-Aksarayî (ö. 1013/1605) - Risâle fî Etvâri's-Seb'a ${ }^{26}$

27. Muhammed b. Halife (ö. 1020/1611) - Etvâru's- Seb 'a ${ }^{27}$

28. Şeyhülislam Kemalpaşazâde (ö. 940/1534) - Risâle-i Nefs ${ }^{28}$

29. Bâlî Efendî Sofyavî (ö.960/1553) - Risâle-i Etvâr-1 Seb ‘a ${ }^{29}$

30. Şücaeddin İlyas b. İsa b. Mecdüddin es-Saruhanî Akhisârî (ö. 967/1559) Risâle-i Etvâr-1 Seb'a $\mathrm{a}^{30}$

31. Şeyh Mustafa b. Seyyid Ali Akşehrî (ö.972/1564) - Risâle ${ }^{31}$

32. Lâ Mekânî Hüseyin Efendi (ö.1034/1624) - Risâle fî Atvâri's-Seb 'a fi's-Sülûk ${ }^{32}$

33. Seyyid İsmail Bedreddin (ö. 1292/1875-6) - Etvâr-1 Seb'a Risâlesi ${ }^{33}$

34. Mehmed Emin Tokadî (ö.1158/1745) - Etvâr-1 Makâmât-1 Hazret-i Ali ${ }^{34}$

35. Müellifi Belli Olmayan - Etvâr-1 Sülûk-i Kadiriyye ${ }^{35}$

36. Ayntâbî Muhammed Emin b. Muhammed Esad'ın (ö. 19 yy) - Ezvâkü'l-Hâlîdî ve Etvârü'n-Nakşbendî̀ ${ }^{36}$

37. Mustafa b. Yusuf Nizameddin (ö.1187/1783) - Etvâr-1 Melâmetiye $\mathrm{e}^{37}$

38. Azîz Mahmud Hüdâyî (ö. 1038/1628) - Risâle-i Etvâr-1 Seb‘a ${ }^{38}$

39. Abdulgaffar b. Ramazan (ö.17. yy) - Risâle-i Etvâr-1 Seb'a ${ }^{39}$

40. Kemâleddin el-Harîrî (ö.1299/1882) - Risâle-i Ta‘bîr-i Vâk1‘ât ${ }^{40}$

\footnotetext{
${ }^{25}$ Seyfullah Kâsım b. Nizâmeddin, el-Atvâru's-seb 'a fì tarîki’s-sûfiyye, İstanbul Belediye Ktp., Osman Ergin Yazma, no: 65, vr. 13-30; Atvâr-ı Seb 'a, Süleymaniye Ktp., Tâhir Ağa Tekke, no: 502, vr. 23-34.

${ }^{26}$ Şah Veli b. Muhammed b. Kaya Nâib el-Aksarayî, Risale fi Etvari's-Seb'a, Süleymaniye Ktp., Halet Efendi, nr. 827/8, vr. 56b-68a.

${ }^{27}$ Muhammed b. Halife, Etvaru's-Seb'ati'l-Ledünniyye, Süleymaniye Ktp., Hekimoğlu, nr. 438/1, vr. 1b-40a.

${ }^{28}$ Kemalpaşazâde, Risâle-i Nefs, Süleymaniye Ktp., İbrahim Ef., nr. 871/11, vr. 240b-242a.

${ }^{29}$ Bâlî Efendi Sofyavî, Etvâru's-sâlikîn, Süleymaniye Ktp., Hekimoğlu nr. 438/4, vr. 65ab; Ali Haydar Bostanc1, Tasavvufta Etvâr-ı Seb'a ve Sofyalı Bâlî Efendi'nin Etvâr-ı Seb'ası, Yüksek Lisans Tezi, Marmara Üniversitesi, İstanbul 1996.

${ }^{30}$ Şucaaddin İlyas Akhisarî, Risâle-i Etvar-ı Seb 'a, Süleymaniye Ktp., Halet Efendi, nr. 820/3, vr. 19a-25a.

${ }^{31}$ Şeyh Mustafa b. Seyyid Ali Akşehrî, Risâle, Süleymaniye Ktp., Uşşaki Tekkesi, nr. 361/2, 27a-50a.

${ }^{32}$ Lâ Mekânî Hüseyin Efendi, Risâle fí atvâri's-seb 'a fi 's-sülûk, İzmir Milli Ktp. Yazmalar Kataloğu, no: 1123/3, vr. 1317.

${ }^{33}$ Seyyid İsmail Bedreddin, Risâle-i Tarîkat, İBB. Atatürk Kitaplığı Nadir Eserler Ktp., Osman Ergin Yazmaları, nr. $1244 / 2$, vr. 30a-34a.

${ }^{34}$ Mehmet Emin Tokadî, Etvâr-ı Makāmât-ı Hazret-i Ali, İBB. Atatürk Kitaplığı Nadir Eserler Ktp., Osman Ergin Yazmaları, nr. 1160/04.

${ }^{35}$ Etvar-ı Sülûk-i Kadiriye, Anonim, İBB. Atatürk Kitaplığı Nadir Eserler Ktp., Osman Ergin Yazmaları, nr. 538/04, vr. 22b-24a.

${ }^{36}$ Muhammed Emin Ayntâbî, Ezvakü'l-Hâlidî ve Etvarü'n-Nakşibendi, Süleymaniye Ktp., H. Hüsnü Paşa, nr. 778, vr. 1b$46 \mathrm{~b}$.

${ }^{37}$ Etvâr-ı Melâmetiyye, İBB. Atatürk Kitaplığı Nadir Eserler Ktp., Belediye Yazmaları, nr. 393, vr. 104b-107a.

${ }^{38}$ Azîz Mahmud Hüdâyî, Risâle der Beyân-ı Etvâr-ı Seb ‘a, Süleymaniye Ktp., H. Şemsi Güneren, nr. 61/12, vr. 101b-103b.

${ }^{39}$ Abdülgaffar b. Ramazan, Risâle-i Etvâr-l Seb ‘a, Süleymaniye Ktp., Fatih, nr. 5335/6, vr. 88a-b.

${ }^{40}$ Kemâleddin el-Harîrî, Risâle-i Ta 'bîr-i Vakı'ât, İBB. Atatürk Kitaplı̆̆ı Nadir Eserler Ktp., Osman Ergin Yazmaları, nr. 59/7, vr. 93a-95a.
} 
41. Müellifi Belli Olmayan - Etvâr-1 Sûfiyye ${ }^{41}$

42. Şeyh Ömer Fuâdî (ö. 1046/1636-7)- Beyân-1 Etvâr-1 Seb`a ${ }^{42}$

43. Hasan Ünsî Efendi (ö. 1136/1723) - Etvâr-1 Seb'a ${ }^{43}$

44. Muhammed b. Ali el-Malatî (ö. 1105/1693) - Etvâr-1 Seb'a ${ }^{44}$

45. Cemâleddin Edirnevî Uşşakî (ö. 1164/1751) - Risâle fî̀ Beyâni Etvâr-1 Sülûk ve Ba'zı Makâmât ${ }^{45}$

46. La'lî el-Fenâyî el-Gülşenî (ö. 1112/1701) - Etvâr-1 Seb'a ${ }^{46}$

47. Ahmed Müsellim Efendi (ö.1166/1752) - Şerh-i Kasîde-i Şümûun Lâmî‘ fî Beyân-1 Atvâr-1 Seb'a ${ }^{47}$

48. Hilmi b. Muhammed Tâhir - Tasavvufa Dair Bir Risâle ${ }^{48}$

49. İbrahim Hakk1 Erzurûmî (ö.1186/1772) - Atvâr-1 Seb'a ${ }^{49}$

50. Mehmed Şâkir Efendi (ö. 1269/1852) - Etvâr-1 Seb'a Risâlesi ${ }^{50}$

51. İbrahim - Risâle-i Etvâr-1 Seb'a ${ }^{51}$

52. Müellifi Belli Olmayan - Nüfûs u Seb 'a ${ }^{52}$

53. Ahmed Müsellem Ebu'l-Vefâ Edirnevî (ö. 1168/1754) - Şerh-i Kasîde-i Şumûu'l-Lâmî fî̀ Beyâni Etvâr-1 Seb ‘a ${ }^{53}$

54. Müellifi Bilinmeyen - Atvâr-1 Seb' $\mathrm{a}^{54}$

55. Müellifi Bilinmeyen - Atvâr-1 Seb'a Risâlesi ${ }^{55}$

56. Seyyid Ahmed Cezbî - Kenzü'l-Etvâr ${ }^{56}$

Etvâr-1 seb'a konusunda yazılan bu eserler büyük oranda müstakil olarak, insanı eğitme kasdıyla, didaktik olarak yazılmıştır. Tasavvufta saliki eğitmede ise iki metod benimsemişlerdir. Ruhu arındırmak için kalbin halleri üzerinde durularak yapılan eğitime, rûhânî eğitim denilmiştir. Bu eğitimi benimseyen tarikata girenler seyr ü sülûkunu tamamlamak için letâif-i hamse denilen kalb, rûh, sır, hafî ve ahfâ gibi aşamaları tamamlamak zorundadır. Nefis terbiyesini esas alan ve nefsi

\footnotetext{
${ }^{41}$ Fatma Şengül, Uş̧̧̧̂k̂ilerde Etvâr-ı Seb ‘a, Yüksek Lisans Tezi, Marmara Üniversitesi Sosyal Bilimler Enstitüsü, İstanbul 2009.

${ }^{42}$ Ömer Fuâdî, Beyân-ı Etvâr-ı Seb ‘a, İBB. Atatürk Kitaplığı Nadir Eserler Ktp., Belediye Yazmaları, nr. 981/05, vr. 27b37 a.

${ }^{43}$ Hasan Ünsî, Etvâr-ı Seb ‘a, İBB. Atatürk Kitaplığı Nadir Eserler Ktp., Osman Ergin Yazmaları, nr. 1508/02, vr. 7b-11a.

${ }^{44}$ Muhammed b. Ali el-Malatî (Niyazi Mısrî), Etvar-ı Seb 'a, Süleymaniye Ktp., Hacı Mahmut Ef., nr. 2923/4, vr. 78a-85b.

${ }^{45}$ Cemâleddin Edirnevî, Etvâr-l Sülûk Hülasası, Süleymaniye Ktp., Hacı Mahmut Ef., nr. 2713/1, vr. 1b-10a.

${ }^{46}$ La'lî el-Fenâyî el-Gülşenî, Etvar-ı Seb 'a, Süleymaniye Ktp., Bağdatlı Vehbi, nr. 2089/2, vr. 4b-11b.

${ }^{47}$ Ahmed Müsellim Efendi, Şerh-i Kasîde-i Şümûun Lâmî‘ fî Beyân-ı Atvâr-ı Seb 'a, Süleymaniye Ktp., Hacı Mahmud Efendi, no: 3673, vr. 1-83.

${ }^{48}$ Hilmi b. Muhammed Tahir, Tasavvufa Dair Bir Risale, Süleymaniye Ktp., Hac1 Mahmut Ef., nr. 3088/4, vr. 34b-36a.

${ }^{49}$ İbrahim Hakkı Erzurûmî, Atvâr-l Seb 'a, Süleymaniye Ktp., Esad Efendi, no: 1438, vr. 159-186.

${ }^{50}$ Mehmed Şâkir Efendi, Etvâr-ı Seb ‘a Risâlesi, Süleymaniye Ktp., Yazma Bağışlar, nr. 6671/5, vr. 89b-102b.

${ }^{51}$ İbrahim, Risâle-i Etvâr-ı Seb 'a, Süleymaniye Ktp., Uşşaki Tekkesi, nr. 36/7, vr. 37b-41b.

${ }^{52}$ Nüfûs u Seb 'a, Anonim, Süleymaniye Ktp., Reşid Efendi, nr. 1003/35, vr. 528b-530a.

${ }^{53}$ Ahmed Müsellem Ebu'l-Vefâ Edirnevî, Şerh-i Kaside-i Şumûu 'l-lâmî fi Beyân-ı Etvâr-ı Seb ‘a, Millet Yazma Eser Ktp.,

Ali Emiri sry., nr. 912, vr. 1b-44a.

${ }^{54}$ Etvâr-l Seb 'a, İstanbul Belediye Ktp., Muallim Cevdet, no: 40.

${ }^{55}$ Atvâr-ı Seb 'a Risâlesi, Beyazıt Devlet Ktp., Veliyyüddin Efendi, no: 3607, vr.11.

${ }^{56}$ Kenzü'l-Etvâr, Milli Kütüphane, 06 Mil Yz. A 1783.
} 
arındırmak için etvâr-1 seb'a denilen emmâre, levvâme, mülhime, mutmainne, râziye, marziye ve kâmile gibi yedi tavrı benimseyerek eğitim veren tarikatlara ise nefsânî tarikatlar denilmiştir. (Yılmaz 2004: 231-236; Türer 2003: 143) Nefsânî tarikatlar arasında etvâr-1 seb'a eğitimine en fazla önemi veren ise Halvetîlerdir. Halvetîlikte nefis terbiyesi üzerinde daha fazla durulmuş ve bu konuda bir çok eser verilmiştir. Dîvanını inceleyeceğimiz Vâhib Ümmî de bir Halvetîdir.

Vâhib Ümmî'nin tam adı Abdülvehhâb el-Ümmî el-Elmalî el-Halvetî’dir. (Tatc1-Ögke 2018: 18; Ayvansarâyî 365: 42b; Nail Tuman 2001: 1149; Kuyumcu ts.:371; Torun 1989: 14-17; Müstakimzâde Süleyman Sadettin 2000: 433) Antalya'nın Elmalı ilçesinde dünyaya gelen Vâhib Ümmî, H. 1 Şa'bân 1004/ M. 30 Mart 1596'da doğduğu ilçe olan Elmalı'da vefat etmiştir. (Ayvansarâyî 365: 41b; Nail Tuman 2001: 1149; atc1-Ögke 2018: 18; Süleyman Fikri 1338: 186; Evliya Çelebi 2011: IX/143) Vâhib Ümmî, Halvetiye ${ }^{57}$ tarîkatinin Ahmediyye kolunun kurucusu Yiğitbaşı Ahmed Marmaravî’ye (ö.910/1504) bağlıdır. (Marmaravî 1343:44a; Marmaravî2745/1: 4b; Şeyhî Mehmed Efendi 1989: 50; Ayvansarâyî 365:41b; Nail Tuman 2001: 1149; Ögke 2001: 47-48)

“Abdülvehhâb Ümmî'nin, Yunus Emre ve üstadı Yiğitbaşı'nın tesir ve üslûbunda kaleme

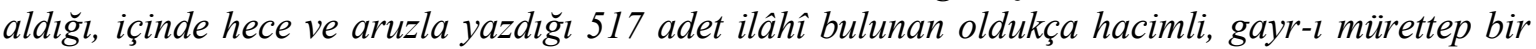
dîvânı vardır. Hz. Şeyh bu nutk-ı şeriflerinde Vâhib, Vâhibî, Vâhib Ümmî, Vehhâb, Vehhâbî gibi mahlaslar kullanmıştır.

Vâhib Ümmî, düşünce ve şiirleriyle kendinden sonra gerek silsilesinden gelen ve gerekse diğer tarîklere mensup pek çok sûfîyi etkilemiştir. Bunların başında Eroğlu Yahşi, Mazharî, Ümmî Sinân, Zuhûrî, Armağan, Niyâzîi-i Mısrî, Çavdaroğlu, Matlaî, Şeyhî, Nüzûlî, Sabrî, Seyyid, Verdî ve Nâzikî gibi şairler gelmektedir. Bu şairlerden, XIX. Asırda yaşayan Kuşadalı İbrahim Efendi müntesibi Ahmed Nâzikînin (ö. 1856) dîvânındaki "Nâzikî" mahlaslı bazı şiirler Vâhib Ümmî̀ye aittir." (Tatc1-Ögke 2018:57-58)

Vâhib Ümmî’nin sadece Dîvânı vardır. Dîvan 517 manzûmeden oluşmaktadır. Bu çalışmada divandaki manzumelerden hareketle onun nefsin yedi mertebesi ile ilgili görüşlerini inceleyeceğiz.

\section{Vâhib Ümmî'de Etvâr-ı Seb'a}

Vâhib Ümmî, Halvetiyye geleneğine uygun olarak seyr ü sülûkun yedi aşamanın geçilmesi neticesinde tamamlanacağı esasını benimsemiştir. Yine geleneğe uygun olarak etvâr-1 seb 'adan, yedi tavr, yedi deniz, kalbin ve nefsin yedi evresi olarak bahsetmiş̧tir. Bunlar; emmâre, levvâme, mülhime, mutmainne, râzıyye, marziyye ve kâmiledir. Bu mertebelerin aşılması seyr ü sülük olarak bilinir ki her bir mertebede Allah'ın bir ismi zikredilir. Emmârede Lâ ilâhe illallah, levvâmede Allah, mülhimede Hû, mutmainnede Hak, râziyede Hay, marziyyede Kayyûm ve kâmilede ise Kahhâr ismi zikredilerek günlük virdler yapılır. ${ }^{58} 242$. Manzumede etvâr-1 seb'a ve makamları izah eden Vâhib Ümmî, bunların erenlerden öğrenilebileceğini ifade eder.

Vâhib Ümmî, şiirlerinde yedi tavrı ve her mertebedeki sırları izah etmiştir. Evliyânın kervanına katılan kimselerin, her birinin deniz olan bu mertebeleri geçeceğini, ancak aşk ehli olanın bu tavırları anlayacağını söylemiştir.

Yedi tavr üzre Vehâbî mazharısın Vâhid'in

Ehl-i aşk olan kişi burdan nişân vermek gerek

\footnotetext{
${ }^{57}$ Geniş bilgi için bkz. Hulvî-zade Cemaleddin, Lemazât-ı Hulviyye, Süleymaniye Ktp. Hacı Mahmud Bl. Nu. 430, vr. 118a-151b; Sâdık Vicdânî: Tomar-ı Turuk-ı Aliyye, Tarikatlar ve Silsileleri, (Haz. İrfan Gündüz), İstanbul 1995; Şapolyo, Enver Behnan: Mezhepler Ve Tarikatler Tarihi, İstanbul 1964; Yaşar Nuri Öztürk, Kuşadalı İbrahim Halveti, İstanbul 1982; Rahmi Serin, İslam Tasavvufunda Halvetîlik ve Halvetîler, İstanbul 1984; Himmet Konur, İbrahim Gülşenî, Hayatı, Eserleri, Tarikati, İstanbul 2000.

${ }^{58} \mathrm{Bu}$ zikirlere esmâ-yı seb`a denir. Allah'ın güzel isimlerinden yedi tanesi: İllallah, Allah, Hû, Hak, Hayy, Kayyûm, Kahhâr.
}

Turkish Studies - Religion, 15(1) 
Yedi tavr üzre kerâmet sırrının tahtında sen

Hürmetinden ayrı düşme berk yapış erkâna sen (180/8)

Yedi tavr üzre dedik bu tevhidin ahvâlini

Ol sebebden şübhesiz bu ma'nadan bulduk necât

Yedi tavr üzre iken âlim durur tevhîde cân

Ey birâder evliyâdır bize ayân öğreden

Yedi tavr üzre içerden âşıka budur nidâ

Tevhidin ma'nâsını rûhumda pinhân eyledim

Evliyânın katarına n'olaydın sen dirkeneydin

Yedi deniz dokuz sıfat eğlenmeyip geçerdin sen(434/3)

\section{Nefs-i Emmâre}

Etvârı Seb'anın birinci tavrı, ilk aşaması nefs-i emmâredir. Kötülügü emredici, emir ve yasaklara uymayan, şehvet peşinde koşan, dünyevî ve süflî şeylere meyleden, üzeri örtülü, çirkin ve kötü ahlakın kaynağı olan nefisdir. (Hüseyin Kazım Kadri 1943: 532; Cürcânî ts.: 243; Cebecioğlu 2014: 364; Çelebi Halife 438: 42a; Akhisarî 820/3: 19a) "Ben nefsimi temize çıkarmam, çünkü Rabbimin merhamet ettiği hariç, nefis aşırı derecede kötülügü emreder. Şüphesiz Rabbim çok bağışlayandır, çok merhamet edendir" dedi." (Yûsuf 12: 53) âyet-i kerîmesinde geçen nefs-i emmâre ibaresinden mülhemdir. Kötülügün kaynağı olan bu nefsin yedi sıfatı bulunmaktadır. Bunlar: cimrilik, hırs, cehalet, kibir, şehvet, gazap, haset. (Yusuf Sinan b. Ali 341/02: 23b, 24a)

Nefs-i emmârenin makamı sadr'dır. Bu makamda lâ ilâhe illallah zikredilir. (Bâlî Efendi Sofyavî 1b-2a; Bâlî Efendi Sofyavî 2338: 31a)

Vâhib Ümmî’ye göre bu mertebede olan kişinin kalbi kötülükle doludur. Mümine selam vermez. Nefsini emmâreden kurtarmadan ölen kişi mahşer yerinde hayvan suretinde görünür. $\mathrm{Bu}$ nefiste olan kişi insana zarar verir. Nefs-i emmârede olanı aşk ve irfanla islâma, imâna ve ihlâsa davet eder.

Mü'mini görse kaçar vermez selâm ucb ehlidir

Dopdolu anın içi emmâredir kalbi harâb

Bakagör tevhîd ile nefsindeki emmâreyi

Giremez İblîs gelip bu tevhidin arasına

Nefsini emmâreden kurtarmayan âdam değil

Korkudur mahşer yerinde sûreti hayvân olur

Dediler emmâreden eyle hazer sokar seni

Ol sana dolaşmasın zünnâr-1 dünyâdan sakın

Nefsini emmâreden kurtarmadan şeyhin senin

Farz u sünnet hiç değil ol kuru tâc neyler sana (487/10) 
Bu mertebede olan kişide kin, kibir, buğzetmek ve hasetlik olur. Sürekli herşeyi bilirim diyerek gezer. Nefsini bilenin bu mertebeden kurtulacağını söyler ve bunu şiirlerinde izah ettiğini ifade eder.

Kin ü kibr buğz u hased tahtında bir dîvânesin

Yürü var korumamışsın nefsini mekkâreden

Anladım bildim diyü da'vâ edersin halka sen

Bildiğin bilsem nedir bu gizliden eşkâreden

Ârife mesken değildir dü cihânın lezzeti

Sen umarsın aşka mazhar düşmeyen âvâreden

Anladım hâlen seni ikrâr u inkâr eyledin

Haberin yok zerrece üstündeki seyyâreden

"Men aref" ma'nâsının sırrın sana etdim beyân

Er isen kurtar bugün sen nefsini mekkâreden

(389/3-7)

\section{Nefs-i Levvâme}

Etvârı Seb'anın ikinci tavrı, ikinci aşaması nefs-i levvâmedir. Bu nefsin makamı kalptir. (Cürcânî ts.: 243; Abdülgaffâr b. Ramazan 746/9: 172a; Hilmi b. Muhammet Tahir 3088/4: 35a) Kınayıcı nefistir. (Cebecioğlu 2014: 365; Karamanî, 27a) "(Kusurlarından dolayı kendini) kınayan nefse de yemin ederim (ki diriltilip hesaba çekileceksiniz). " (Kıyâmet 75:2) âyet-i kerîmesinde geçen nefs-i levvâme'den mülhemdir. Çekiştirme, kınama, aşağılama, zemmetme vardır. Bu mertebede kişi, henüz kendini kötülükten alıkoyacak dereceye gelmemiş olmakla berâber yaptığı kötü işlerden vicdan huzursuzluğu duyup kendine levmeder, kendini suçlar. Kendini kötülüklerin farkına varması sebebiyle kınar. İyilik ili kötülük, ilahi nur ile şeytani duygu arasında gider gelir. Hem kötülük yapar hem de yaptıklarından pişmanlık duyar. İşlediği kötülükten dolayı da Allah'tan affını ister. (ÇelikY1ldırım 2018: 33-34)

"Bu mertebede nefsin sıfatları "yerme", "heves", "mekir", "ucub”, "işret", "temenni" ve "kahır"dır. Bu mertebede sâlikin seyri, Allah için yolculuk anlamına gelen "seyr lillah"tır. Sâlik nefsi levvâmede "Allah, Allah, Allah" diyerek ism-i Zâtı zikreder ve bu ismin hürmetine nefsini yenmeye muvaffak olur. (Muslu 2007: 52)

$\mathrm{Bu}$ nefsin kurtulunması gereken yedi kötü sıfatı vardır: Kınama, kendini beğenme, kahır, temenni, hile, heves, işret. (Muslu 2007: 33) Vâhib Ümmî’ye göre levvâme mertebesinin sırrını ancak Hak ehli bilir. Levvâmenin sırrını ayet ve hadislerle açıklamıştır. Levvâme mertebesini geçemeyen kişiler Işıklığa ulaşamaz.

Ehl-i Hak'dan gayrı kimse anlamaz esrârımı

Bu makâm levvâmedir sırrın nişân vermek gerek

Âyet ile hadîs ile verdim haber anlayana

Bundan öte içeriye levvâmeye seyrân gerek

Bunların hep cümlesi levvâmenin tahtındadır

Nefslerin fehm etdiler merdân gezer abdâllar 
Ol levvâme sıfâtıdır sana lâyık değildir ol

Hakîkatdir bu söz sana eremezsin Işıklığa

\section{Nefs-i Mülhime}

Etvârı Seb'anın üçüncü tavrı, üçüncü aşaması nefs-i mülhimedir. Makamı ise ruhtur. (Hüdâyî, 4a; Karamânî 27a; Çelefi Halife, 438/2: 51b) İlham ve keşfe nail olan nefstir. (Cebecioğlu 2014: 366) "Ruh, ilâhî isimlerin sûreti olduğu için ayrica özel bir sûrete sahip değildir. İlâhî isim ve sıfatların ma'rifetine mahal teșkil eder. Fiillerden fenâ makâmı, ilâhî isimlerin tecellîsiyle meydana gelir. Rûh makamının seyri, Allah'a yolculuk anlamına gelen "seyr alellâh"tır. Sehâvet, kanâat, ilim, tevâzû, tövbe, sabır ve tahammül bu makamın özelliklerindendir. Sâlikten de çoğunlukla bu gibi hâller zuhûr eder. Sâlik bu mertebede "Hû, Hû, Hû" diyerek zikreder." (Muslu 2007: 54) "Nefse ve onu düzgün bir biçimde şekillendirip ona kötülük duygusunu ve takvasını (kötülükten sakınma yeteneğini) ilham edene andolsun ki, nefsini arındıran kurtuluşa ermiştir." (Şems 91:7-9) âyet-i kerîmesinde geçen fe-elhemehâ kelimesinden mülhemdir.

Bu mertebede nefis iyiyi ve kötüyü birbirinden ayırır. Nefis ruh âlemine yönelerek aşka gark olur. Gayba ait hususlar keşf yoluyla açılır ve manevi ilerleme keşf yoluyla sağlanır. (Kuşeyrî 1978: 75-76) Bu mertebede kötü ahlaklar gider ve yedi güzel ahlak kazanılır. Bunlar: sabır, ilim, cömertlik, doğruluk, tevazu, tahammül, kanaat. Bu nefiste daima hayr vardır. (Cebecioğlu 2014: 366; Mehmet Şakir Halvetî 6671/5: 90b; İbrahim 36/7: 38b) "Bu merhalede sufinin iç dünyasında hasıl olan ilahi isimlerin tecellileri sebebiyle salikin fiilleri Hakk' in fiillerinde fena bulur. Sufi birçok manevi hali bu merhalede tecrübe eder. Bu sebeple bu tavır fütuh menzili (manevî fetihler) ve ruhun makamı olarak nitelendirilir." (Usta 2015: 132)

Vâhib Ümmî, nefs-i mülhimeyi daha çok ruh makamının yolculuğu olarak ele almıştır. Seyrullah ise Allah'a yolculuk anlamına gelmektedir ki bu aynı zamanda Hû makamıdır. Allah yoluna giren kişi Hû zikrini çekerek ilerlemelidir. Hû makamına erişen kişi artık aşkın sırlarına vakıf olmuştur. Sırlara vakıf olan kişi için ise canı ve dünyanın bir önemi yoktur.

Şerîatden tarîkatden içerisi sır ilidir

Ak1l ana ârif olmaz mülhemeye vicdân gerek

Seyru'llâhın makâmından evliyânın sırrı budur

Düş elinde gezer iken Tanr'arslanı Alî gördüm

Vehâbî Ahmed'e sordu îmân-1 kâmilin vechin

Hû zikrinin makâmından görünen ayn-1 zatındır(125/5)

Vehâb'ın maksûdu senden Hû zikrinin makâmıdır

Hayâtın nûru hakkıyçün hidâyet eyle yâ Rabbî

Yanmağa geldik bugün "Kâlû belâ"dan derd ile

Hû makâmın zikr eden cân u cihânı neylesin

Hâke yeksân eyledi bu cismimi ol ism-i zât

Düşer isen gel beri Hû'nun makâmına bugün

Hû makâmından gelen esrâr-1 aşkdır cânıma

Hamdüli'llâh çok şükür Kur'ân'a verdim gönlümü 
Yine aşkın kemâlinden dilim tekrâr eder Hû Hû

Yine aşkın cemâlinden dilim tekrâr eder Hû Hû (268/1)

\section{Nefs-i Mutmainne}

Etvârı Seb'anın dördüncü tavrı, dördüncü aşaması nefs-i mutmainnedir. Makamı ise sır'dır. Doyuma, huzura, rahata kavuşmuş nefis anlamına gelir. (Cebecioğlu 2014: 365; Abdülgaffâr b. Ramazan 2478/2: 31b; Azîz Mahmud Hüdâyî 61/12: 4b-5a; Çelebi Halîfe, 44a) Sır, "sadece Allah'ın bildiği ya da az sayıda insan tarafindan bilinen özel bilgi" ve "ruhun bir idrak mertebesi" olmak üzere iki anlamda kullanılır. Kul ile Allah arasında kalan gizli hallerdir. (Tosun 2009: 115-116) Seyr ü sülük neticesinde elde edilebilen bu sırlar saklanır ve başkalarına ifşa edilmez. (Kuşeyrî 1978:88)

"Sûfiler tarafindan sir kavramı ile ilgili ortaya konan tanımlardan bir diğeri de sirrın ruh gibi beden kalıbına tevdi edilmiş bir latife olmasıdır. Sirrı bu manası ile ele alan sûfiler insan benliğinin beden, nefs, kalp, ruh ve sir gibi iç içe geçmiş latifelerden meydana geldiğini belirtmişlerdir. Buradaki latifeden kasit insan benliğinin katmanları ve boyutlarıdır. Kimi sûfiler sırrı ruhun üstünde bir latîfe olarak nitelerken bir kismı da sirrı ruh ile kalp arasında bulunan bir latîfe olarak tarif etmislerdir. Tüm bunlar sûfilerin nefs yahut kalb ismi altında latîf bir cisim olarak tarif ettikleri insan benliğinin manevî arınma neticesi elde ettiği üstün idrak seviyeleridir. Nitekim sûfillerin ifadelerine göre nefsin yahut kalbin saflaşması rûh, daha da saflaşması sırr adını almaktadır." (Usta 2015: 148)

"(Allah şöyle der:) "Ey huzur içinde olan nefis!", "Sen O'ndan razı, O da senden razı olarak Rabbine dön!", (Iyi) kullarımın arasina gir.", "Cennetime gir." (Fecr 89: 27-30) âyet-i kerîmesi ile "Onlar, inananlar ve kalpleri Allah'ı anmakla huzura kavuşanlardır. Biliniz ki, kalpler ancak Allah'ı anmakla huzur bulur." (Ra'd 13: 28)) âyet-i kerîmelerinde geçen nefs-i mutmainneden mülhemdir. "en-Nefsü'l-Mutmainne" korku ve hüznün tesirinden kurtulmuş, güven ve istikrar bulmuş nefistir. (Usta 2015: 150)

$\mathrm{Bu}$ mertebenin seyri seyr ma'allah yani Allah ile yolculuktur. Zikri ise "Hak"tır. Bu mertebeye ulaşan kişide cömertlik, rıza, ihsan, ibadet, şükür, tevekkül, alçak gönüllülük gibi ahlaki özellikler görülür. (Muslu 2007: 56; Çelik-Yıldırım 2018: 35)

Dördüncüsü mutmainne Mansûr bilir bu menzili

Er yüzünden erişmeğe ikrâr eder bir cân gerek

Hak Taâlâ sırrının nûrunda gark oldu özüm

Hamdülillâh çok şükür dost vechini gördü gözüm

Cân ilinden zâhir oldu dilime budur sözüm

Şimdi bir âlemdeyiz sûretd'olan bilmez bizi

Gönlüme ilhâm olan ma'nâyı gör dizâr imiş

Rûhumun şerh etdiği nutkumdaki esrâr imiş

Hak Taâlâ zâtının sırrındaki bâzâr imiş

Şimdi bir âlemdeyiz firkatd'olan bilmez bizi

Vehâbî cânına eren nidâdır

Hak'1n zikri nuru câna gıdâdır

Bu sırra "lâ" demek ayn-1 hatâdır

Melûl olma gönül "el-hükmü li'llâh" 
"Ene'l-Hak"dan dedi Mansûr anınçün düşdü gavgâya

Bu sırrı sen nihân eyle eğer insân isen insân

$(300 / 13)$

\section{Nefs-i Râziye}

Etvârı Seb'anın beşinci tavrı, beşinci aşaması nefs-i mutmainnedir. Makamı ise hafî' dir yani sırru's-sır'dır. Razı olan, hoşnut kalan nefis anlamına gelir. (Cebecioğlu 2014: 366; Bâlî Efendi Sofyavî, 14a; Cemâleddin İshak Karamanî, 25b; İbrahim, 4ab, 41a) Sırru's-sır ise sadece Allah'ın bildiği şeylerdir. Kişinin kendi iradesinden, benliğinden vazgeçip Hakk'ın iradesine tabi olması, kendi bilinci ve şuurunu yitirmesidir. (Cebecioğlu 2014: 366; Usta 2015: 161)

"(Allah şöyle der:) "Ey huzur içinde olan nefis!", "Sen O'ndan razı, O da senden razı olarak Rabbine dön!", (Iyi) kullarımin arasina gir.", "Cennetime gir." (Fecr 89: 27-30) âyet-i kerimesindeki "râziyeten marziyye" ibaresinden mülhemdir. Kişi bu mertebede Allah'ın rızasna ulaşır. O'nun yaptığı herşeyden hoşnut olur, halini beğenir ve halinin devamını ister. Allah'ın takdir ettiği bütün şeylere tam bir teslimiyetle rıza gösterir. Bu mertebenin seyri, seyr fillah ve fena fillah'tır. Zikri ise Hay'dır. (Usta 2015: 162; Muslu 2007: 58; Çelik-Yıldırım 2018: 35-36)

Bu mertebede hakka'l-yakîn mertebesine ulaşan sâlikte kerâmet, zikir, ihlas, zühd, vefâ, riyazet, vera gibi özellikler belirir. (Muslu 2007: 57; Çelik-Yıldırım 2018: 35-36)

İhtiyârım elde değil lâzım geldi söylemesi

Beşincisi kerâmetdir ayân değil nihân gerek

Ey gönül dervîş isen hâk ile yeksân ol yürü

Gayrısı lâzım değil ma'nâda sultân ol yürü

Âşıka budur nişân ayne'l-yakîn hakka'l-yakîn

Ad u sanı terk edip dillerde destân ol yürü

Himmet eyle kendine hiç gelmesin akl-ı beşer

$\mathrm{Bu}$ şarâb-1 şevk ile sen şöyle mestân ol yürü

Aklın ile cismini eyle fenâ li'llâh içün

Bu kemâl-i aşk içün deryâ-yı ummân ol yürü

$(248 / 1-4)$

Anladınsa Vâhib'i cismimde cândır söyleyen

San'atım hakka'l-yakîn zâtında seyrândır benim

Cân ü dilden dediler "yâ Hayyu Kayyûm es-Samed

Ahmed'in zikrindeki Rahmân'a gelmişlerdeniz

\section{Nefs-i Marziyye}

Etvârı Seb'anın altıncı tavrı, altıncı aşaması nefs-i marziyye'dir. Makamı ise kürŝ̀'dir. Hoşnut olunan, kendisinden razı olunan nefstir. Beşerî istekleri terk etmiş, güzel huyları edinmiş, kusurları affeden, şefkatli, eli açık, insanları sırf Allah rızası için seven Allah'ın kendisinden razı olduğu nefstir. Seyr ü sülûku ise seyr anillah'tır. Bu mertebeye ulaşan kişi ise Kayyûm'dur. (Cebecioğlu 2014: 366; Usta 2015: 172; Çelik-Yıldırım 2018: 36; Azîz Mahmud Hüdâyî, 6a; Cemâleddin İshak Karamanî, 27a) 
"Rableri katında onların mükafatı, içlerinden ırmaklar akan, içlerinde ebedi kalacakları Adn cennetleridir. Allah onlardan razı olmuştur, onlar da Allah'tan razı olmuşlardır. İşte bu mükafat Rablerine derin saygı duyanlara mahsustur. " âyet-i kerîmesindeki"radiya'llâhu anhum ve radû anh" ibaresi ile "(Allah şöyle der:) "Ey huzur içinde olan nefis!", "Sen O'ndan razı, O da senden razı olarak Rabbine dön!", (Iyi) kullarımin arasina gir.", "Cennetime gir." (Fecr 89: 26-30) âyet-i kerimesindeki "râziyeten marziyye" ibaresinden mülhemdir.

Bu mertebeye ulaşan kişide; Allah'1 tefekkür etmek, Allah'ın ahlak1 ile ahlaklanmak, dünyayı ve beşeriyeti terketmek, insanları sırf Allah için sevmek, Allah'a yakınlık, Allah'ın nuruyla nurlanmak gibi özellikler görülür. (Cebecioğlu 2014: 365; Çelik-Yıldırım 2018: 36)

Yol erinin tevhîdini ârif gerek anlamağa

Altıncısı marzıyyedir bunda bürhân Kur'ân gerek

Dilimin şerh etdiği yâ Hayyu Kayyûm es-Samed

Dâimâ şükrüm budur biz enbiyâ şakirdiyiz

Murâd aşk-1 İlâhî'den nağam ilhâm eden Hak'dır

Şifâ-yı ism-i a'zamdır marzıyye nediğin bilsin

\section{Nefs-i Kâmile}

Etvârı Seb'anın yedinci tavrı, yedinci aşaması nefs-i kâmile'dir. Makamı ise ahfâ'dır. Seyr billah, Allah ile yolculuk mertebesidir. Nefs olgunlaşmış, Hakk'ın zatında yok olmuştur. İrşad makamına yükselen bu nefse nefs-i kudsîyye ve nefs-i sâfiyye de denilmektedir. (Muslu 2007: 60; Cebecioğlu 2014: 365; Çelik-Yıldırım 2018: 36;)Bu mertebede nefis ruha dönüşür. Nefis ruha dönüşerek aslî vatanına ulaşmış olur. Bu sebeple kudsî ruh olarak isimlendirilir. Bu sebeple bu mertebedeki nefse, nefs-i kâmile denilmektedir. Bu mertebeye ulaşan kişi ise Kahhâr'dır. (Usta 2015: 192)

"O, sizi bir tek candan yaratandır. Sizin bir karar kllma yeriniz, bir de emanet birakulma yeriniz var. Biz anlayan bir toplum için âyetleri ayrı ayrı açıklamışızdır." (En'âm 6:98) âyet-i kerîmesi ile "(Peygambere olan mesafesi) iki yay aralığ kadar, yahut daha az oldu.Böylece Allah kuluna vahyedeceğini vahyetti.Kalp, (gözün) gördüğ̈̈nü yalanlamadı.”, (Necm 53:9) âyet-i kerimesinden mülhemdir.

Etvâr-1 seb'anın en mükemmel tavrı, nefs-i kâmiledir. Bu mertebeye ulaşan kişi seyr ü sülûkunu tamamlar.

Yedincisi safiyyedir halka ayân etmek olmaz

Bundan geçip ulaşmağa cân hazrete kurbân gerek

Bu vücûdum hânesinden vechin izhâr eyleyen

Vâhid ü Ferd ü Ahad ismi anın Kahhâr idi

Ey gönül şâd ol bugün mürşid-i kâmil devridir

Tevhîdin hâsdır senin insân-1 kâmil devridir

Nefsini fehm eyleyenler kâmil-i insân olur

Nefsini fehm etmeyenler câhil ü nâdân olur 


\section{Sonuç}

Vâhib Ümmî etvâr-1 seb'ayı Dîvânı'nda tasavvufi eğitim ve gelişim açısından bir süreç olarak ele almıştır. Bu süreci izleyen sâliklerin insan-1 kâmil olabileceğini birçok manzumesinde vurgulamıştır. Nefsin mertebelerini geçen insanın önce kendisini sonra ise rabbini tanıması aşamalarını lirik bir dil ve metaforik bir üslûbla ifade etmiştir. Onun üslûbu, Yûnus Emre'nin söyleyiş tarzı gibi, sade ve anlaşılırdır.

Tarikatının halkla iç içe olması sebebiyle de halkı eğitmek için, tasavvufî girift konuları halkın anlayabileceği seviyeye indirmiş ve etvâr-1 seb'ayı bir eğitim sistemi olarak kullanmıştır. Şiirlerindeki didaktik yön bunu açık bir şekilde ortaya koymaktadır.

Vâhib Ümmî’ye göre sohbet ve zikr-i dâimî, seyr ü sülükun tamamlanabilmesi için mutlaka gereklidir. Nefsini arındırmayan, yedi esmâ ve yedi makamı geçemeyen sâlik, seyr ü sülûkunu bitiremez. Bu nedenle nefsin son mertebesini tamamlayarak insan-1 kâmil olma yolunda; karşılaşılacak engelleri tanıtmak, yol göstermek, mesafeleri kısa yoldan katetmek için nezih bir üslûbla yukarıda örneklerini verdiğimiz pek çok manzume kaleme almıştır.

Tasavvufa ait bu tür dînî metinlerin dîvân edebiyatı açısından önemi büyüktür. Tasavvuf edebiyatında etvâr-1 seb'a konusunda manzum ve mensur, hem müstakil hem de kitap içinde bir bölüm olarak çok fazla eser yazılmıştır. Eserlerin çerçevesi belli, konuları ise nettir. Bu açıdan etvâr1 seb'a dîvân şairlerince de konu edinilmiştir.

Vâhib Ümmî'nin tasavvufî eğitimini, beden, nefs ve ruh ilişkisi üzerine kurmuştur. Etvâr-1 seb'ayı hem nazarî hem de pratik açıdan ele almıştır. Yedi tavrın her biri için özel bir yöntem geliştiren Vâhib Ümmî, her tavrda özel, Allah'ın farklı bir ismini kullanmıştır. Ki bu isimlerin salikin durumuna göre farklılaşacağını da söylemiştir. Seyr ü sülûkunu tamamlayan kişi önce kendini tanır, kendini tanıyan ise rabbini tanır. Rabbini tanıyan ise gerçek marifete, sırra erer. Yedi tavrı bitiren sâlik, benliğini eritmiş, ahlakını güzelleştirmiş, dünyalı̆̆ Allah için terketmiş, ilâhî tecellilere mazhar olmuştur. İkiliği terkederek, gerçek tevhide ulaşmıştır.

\section{Kaynakça}

Alıcı, L. (2010). Halili-i Mar'aşî Divançe ve Etvar-ı Seba, Kahramanmaraş: Ülke Kitaplığı.

Almaz, H. (2007). Bakü'den Anadolu'ya Yansıyan Işıı Halvetî Pir Seyyid Yahya Şirvânî Hayatı ve Eserleri, Ankara.

Abdülgaffar b. Ramazan, Etvâr-ı Seb'a Risâlesi, Süleymaniye Ktp., Hacı Mahmut Ef., nr. 2478/2, vr. 28a-33a.

Abdülkerim el-Cîlî, Risâle fí Etvâr-ı Seb'a, Süleymaniye Ktp., Yazma Bağışlar, nr. 2998/14, vr. 92b93a (182-183).

Abdulkerim Kuşeyrî, er-Risâletü'l-Kuşeyriye, Tasavvuf İlmine Dair: Kuşeyrî Risâlesi, Çev. Süleyman Uludağ, Dergâh Yayınları, İstanbul 1978.

Abdüllatif Makdîsî, et-Tuhfetu'l-Vâhibü'l-Mevâhib, Süleymaniye Ktp., Cârullah, nr. 2061/49, vr. 187b-193a.

Ahmed Müsellim Efendi, Şerh-i Kasîde-i Şümûun Lâmî̀'fỉ Beyân-ı Atvâr-ı Seb 'a, Süleymaniye Ktp., Hac1 Mahmud Efendi, no: 3673, vr. 1-83.

Ali Hüsâmeddin Bitlisî, Etvâru's-Seb'a, Beyazıt Devlet Ktp., Beyazıd-Veliyuddin Ef., nr. 1795/3 vr. 137b-182a.

Aclûnî, İ. (1988). Keş̧ü'l-Hafâ, I-II, Beyrut: Dâru'l-Kütübi'l-İlmiyye. 
Afîfî, (2006). Füsûsu'l-Hikem Okumaları İçin Anahtar, Çev. Ekrem Demirli, İstanbul: İz Yayınları.

Ağarı, M. (2006). “İslam Coğrafyacılı̆̆ında Yedi İklim Anlayışı”, AÜIFD, sy. II, ss. 195-214.

Edirnevî, A. (1314). Şerh-i Kaside-i Şumûu'l-lâmî fi Beyân-ı Etvâr-ı Seb'a, İstanbul.

Ahterî, M. (1283/1867). Ahterî-yi Kebîr, I-II, İstanbul: Matbaa-i Sultâniye.

Akşemseddin, Ahvâlu's-Sülûk, Süleymaniye Ktp., Tahir Ağa Tekkesi, nr. 334 vr. 84a-85a.

Altıntaş, H. (t.y). Tasavvuf Tarihi, Ankara: Akçağ Yayınları.

Alıcı, L. (2010). Halili-i Mar'aşî Divançe ve Etvar-ı Seba, Kahramanmaraş: Ülke Kitaplığı.

Aşkar, M. (2004). Niyâzî-i Mısrî Hayatı, Eserleri, Görüşleri, II. Baskı, İstanbul: İnsan Yayınları.

Aydın, M. S. (2000). "İnsan-1 Kâmil”, DIA, XXII, 330-1.

Ayiş, M. Ş. (2017). "Sünbül Sinan ve Atvâr-1 Seb'a Risalesi Bağlamında Nefis Mertebeleri", Bingöl Üniversitesi Sosyal Bilimler Enstitüsü Dergisi, 7/13, (2017]: 119-138.

Aynî, M. A. (1985). İslam Tasavvuf Tarihi, sad. H.R.Yananlı, İstanbul: Akabe Yayınları.

Azîz Mahmud Hüdâyî, Risâle der Beyân-ı Etvâr-ı Seb 'a, Süleymaniye Ktp., H. Şemsi Güneren, nr. 61/12, vr. 101b-103b.

Bâlî Efendî Sofyavî, Risâle-i Etvâr-ı Seb'a, Süleymaniye Ktp., Uşşaki Tekkesi, nr. 258/2, vr. 45b$78 \mathrm{a}$.

Vâridât, Süleymaniye Kütüphanesi, Hac1 Mahmud, nu. 2338, vr. 31a. Atvâr-ı Seb`a, vr. 1b-2a.

Bostanc1, A. H. (1996). Tasavvufta Etvâr-ı Seb'a ve Sofyalı Bâlî Efendi'nin Etvâr-ı Seb'ası, Yüksek Lisans Tezi, Marmara Üniversitesi Sosyal Bilimler Enstitüsü, İstanbul.

Bostanc1, E. (1993). Bali Efendi'nin Etvar-ı Seb'a Risalesi ve Etvari-Seb'a'nın Tasavvuftaki Yeri, Yüksek Lisans Tezi, Marmara Üniversitesi Sosyal Bilimler Enstitüsü, İstanbul.

Cebecioğlu, E. (1987). "Prof. Dr. Nicholson'ın Kronolojik Esaslı Tasavvuf Tarifleri”, AÜIFD, Ankara, XXIX, ss. 387-406.

..(2014). Tasavvuf Terimleri ve Deyimleri Sözlüğ̈̈, Ankara: OTTO Yayınları, 6. Baskı.

Cemâleddin Aksarayî (Çelebi Halife), Etvâru'l-Kulûb (Etvâr-ı Seb'a), Süleymaniye Ktp., Hekimoğlu, nr. 438/2, vr. 41a-45b.

,Etvâr-ı Kulûb, Süleymaniye Kütüphanesi, Hekimoğlu, nr. 438/2, vr. 42a.

Risâletü'l-Etvâr, Ankara Adnan Ötüken İl Halk Ktp., nr. 4754, vr. 199b-202a

Cemâleddin Edirnevî, Etvâr-ı Sülûk Hülasası, Süleymaniye Ktp., Hacı Mahmut Ef., nr. 2713/1, vr. 1b-10a.

Cemâleddin İshak Karamanî, Risâle fî Etvâris's-seb`a, vr. 27a.

Sağır, C. (2017). Şah Velî Ayntâbî'nin Atvâr-ı Seb'a Risalesi (Metin-tahlil), Yüksek Lisans Tezi, Hitit Üniversitesi.

Çağbayır, Y. (2007). Ötüken Türkçe Sözlük (1-5), İstanbul: Ötüken Yayınları, c. 2. s. 1512.

Çakmak, M. (2016). "Niyazî-i Mısrî'nin Etvâr-1 Seb'a Adlı Risâlesi'nde Seyr ü Sülûkün Evrelerinde Görülen Rüyâ/Vâkıât", Turkish Studies, 11/5, (2016]: 137-158. 
Çelik, İ.-Yıldırım, B. (2018). Halvetiyye Geleneğinde Etvâr-lSeb`a/Nefsin Mertebeleri, Türk Kültür ve Hacı Bektaş Veli Araştırmaları, Yaz 2018, Sayı 86, s. 33-34.

Demirli, E. (2009). İnsan Metafiziğinde Tanrt ve İnsan, İstanbul: Kabalcı Yayınları.

.(2008). Füsûsu'l-Hikem Çeviri ve Şerhi, II. Baskı, Kabalcı Yay., İstanbul 2008.

(2009). "Sûret", DIA, XXXVIII, 540-541.

(2013). "Yaratma", DIA, XLIII, 329-331.

Ebû Nuaym İsfehânî (1394/1974). Hilyetü'l-Evliyâ, Mısır: Matbaatü’s-saâde.

Ebû Tâlib el-Mekkî (2009). Kûtü'l-Kulûb, Çev. Muharrem Tan, İstanbul: İz Yayınlanı, I/195,175.

E.E. Calverley. (1988)., "Nefis", MEB İslam Ansiklopedisi, İstanbul.

el-Firûzâbâdî, el-Kâmûsu'l-Muhît, (terc. Asım Efendi) ts. II, s. 501-502.

Eraydın, S. (2001). Tasavvuf ve Tarikatlar, İstanbul: MÜIFAV Yayınları.

Erdoğan, K. (1993). "Niyazi-i Mısri hayatı, edebi kişiliği, eserleri ve divanının tenkitli metni", Yayınlanmamış Doktora Tezi, Ankara Ünviversitesi Sosyal Bilimler Enstitüsü, Ankara.

Erginli, Z. (2006). Metinlerle Tasavvuf Terimleri Sözlüğü, İstanbul: Kalem Yayınları.

Ergül, N. (2002). "Kaşânî ve Hakâiku't-Te’vîl fì Dekâiki't-Tenzîl Adlı eserinin I. Cildinin tahkik ve tahrici”, I-II, Basılmamış Doktora Tezi, Harran Üniv. Sosyal Bilimler Ens., Şanlıurfa.

Evliya Çelebi Seyahatnamesi, (Haz. S. Ali Kahraman vd.), YKP Yayınları, İstanbul 2011, s. 143.

Gülaboğlu Mehmed Kütahyalı Askerî, Divan, İBB. Atatürk Kitaplığı Nadir Eserler Ktp., Osman Ergin Yazmaları, nr. 337.

Habib Ömer el-Halvetî, Manzume fì Etvari's-Seb'a, Süleymaniye Ktp., Esad Ef., nr. 1321, vr. 1b51a.

Halilî-i Maraşî, Etvâr-ı Seb'a, Süleymaniye Ktp., Şehid Ali Paşa, nr. 1121/1, vr. 10a-13a.

Hasan Ünsî, Strr-ı Ahadiyet, İBB. Atatürk Kitaplığı Nadir Eserler Ktp., Osman Ergin Yazmaları, nr. $1508 / 01$, vr. 1a-7a.

Hasan Ünsî, Etvâr-ı Seb'a, İBB. Atatürk Kitaplığı Nadir Eserler Ktp., Osman Ergin Yazmaları, nr. $1508 / 02$, vr. 7b-11a.

Hilmi b. Muhammet Tahir, Tasavvufa Dair Bir Risale, Süleymaniye Ktp., Hacı Mahmut Ef., nr. 3088/4, vr. 34b-36a.

Hulvî-zade Cemaleddin, Lemazât-ı Hulviyye, Süleymaniye Ktp. Hacı Mahmud B1. Nu. 430, vr. 118a$151 b$.

Hüseyin Kazım Kadri. (1943). Türk Lügati Türk Dillerinin Işstikakı ve Edebî Lügatları I-IV, İstanbul 1943, s. 532.

Hüseyin Ayvansarayî, Tezkire-i Meşâyıh, Süleymaniye Ktp., Uşşâkî Tekkesi Bl. Yz. Nu: 365, vr. $41 \mathrm{~b}$.

İbn Manzur. (1985). Lisânu'l-Arab, Beyrut 1985, IV, s. 507-508.

İbrahim, Risâle-i Etvâr-ı Seb'a, Süleymaniye Ktp., Uşşaki Tekkesi, nr. 36/7, vr. 37b-41b.

İbrahim Hakk1 Erzurûmî, Atvâr-ı Seb 'a, Süleymaniye Ktp., Esad Efendi, no: 1438, vr. 159-186.

İbrahim Gülşenî, Etvâr-ı Seb’a, Millî Ktp., Yazmalar, nr. 2482/6, vr. 88b-99b. 
İbrahim Kırımî Nidâî, Etvâr Manzumesi, Süleymaniye Ktp., Tahir Ağa Tekkesi, nr. 334-3, vr. 85b$87 \mathrm{~b}$.

İbnü'l-Arabî, Risale fi Etvâri't-Tasavvuf (et-Tasavvufu't-tüsâî), Süleymaniye Ktp., Bağdatlı Vehbi, nr. 704/2, vr. 40b-66a.

Işıtan, İ. (2017). "Cemal Halveti (ö. 899/1494]'nin Etvâr-1 Seb'a Anlayışının Sûfî Psikolojisi Açısından Tahlili", Journal ofHistory Culture and Art Research, 6/4, (2017]: 680-696.

...(2011). "Halvetiyye Geleneğine ve Bir Halvetiyye Şeyhi Olan Sofyalı Bâlî Efendi'ye Göre Sülûkün Yedi Evresi (Atvâr-1 Scb'a)", Hikmet Yurdu, 4/7, (2011]: 89-113.

Kara, M. 2010). Tasavvuf ve Tarikatlar Tarihi, VIII. Bask1, İstanbul: Dergah Yayınları.

Kaşânî, A. (1413/1992). Mu'cemu istılâhâti's-sûfiyye, Thk. Abdülâl Şahin, I. Baskı, Kâhire: Dâru'lMenâr.

Kaymak, O. (1992). Abdüllatif el-Makdisi'nin Hayatı ve Tuhfetü Vâhibi'l-Mevahib fì Beyâni'lMakamât ve'l-Merâtib adlı eserinin tahkiki, Yüksek Lisans Tezi, Marmara Ünviversitesi, Sosyal Bilimler Enstitüsü, İstanbul.

Kemalpaşazâde, Risâle-i Nefs, Süleymaniye Ktp., İbrahim Ef., nr. 871/11, vr. 240b-242a.

Kemâleddin el-Harîrî, Risâle-i Ta'bîr-i Vakı'ât, İBB. Atatürk Kitaplığı Nadir Eserler Ktp., Osman Ergin Yazmalar1, nr. 59/7, vr. 93a-95a.

Kur'ân-ı Kerîm Meâli, çev. Halil Altuntaş \& Muzaffer Şahin, Diyanet İşleri Başkanlığı Yayınları, Ankara 2009.

Kuloğlu Mustafa, Manzum Etvâr-l Seb 'a, Süleymaniye Ktp., nr. 1003/22, vr. 346b-388b.

Kuyumcu, F. (t.s.). Evliyânın Dilinden, Ankara: Nur Yayınları, s. 371.

Küçüktiryaki, F. (2017). XVI ve XVII. Yüzyıllarda Osmanlı Toplumunda Yazılan Atvâr-ı Seb'a Eserlerinin Mukayeseli Değerlendirilmesi, Yüksek Lisans Tezi, Hitit Üniversitesi.

Konur, H. (2000). İbrahim Gülşenî, Hayatı, Eserleri, Tarikati, İstanbul: İnsan Yayınları.

Lâ Mekânî Hüseyin Efendi, Risâle fî atvâri’s-seb‘a fi’s-sülûk, İzmir Milli Ktp. Yazmalar Kataloğu, no: $1123 / 3$, vr. 13-17.

La’lî el-Fenâyî el-Gülşenî, Etvar-ı Seb 'a, Süleymaniye Ktp., Bağdatlı Vehbi, nr. 2089/2, vr. 4b-11b.

Mehmed Şâkir Efendi, Etvâr-ı Seb ‘a Risâlesi, Süleymaniye Ktp., Yazma Bağışlar, nr. 6671/5, vr. 89b-102b.

Mehmet Emin Tokadî, Etvâr-ı Makāmât-ı Hazret-i Ali, İBB. Atatürk Kitaplığı Nadir Eserler Ktp., Osman Ergin Yazmaları, nr. 1160/04.

Muhammed Emin Ayntâbî, Ezvakü'l-Hâlidî ve Etvarü'n-Nakşibendi, Süleymaniye Ktp., H. Hüsnü Paşa, nr. 778, vr. 1b-46b.

Muhammed b. Ali el-Malatî (Niyazi Mısrî), Etvar-ı Seb`a, Süleymaniye Ktp., Hacı Mahmut Ef., nr. 2923/4, vr. 78a-85b.

Mustafa Karahisârî Ahterî, Ahterî-i Kebîr, İstanbul 1283, Matbaa-i Sultâniyye, c. II, s. 15.

Muslu, R. (2007). "Halvetiler'de Atvâr-1 Seb'a Yazma Geleneği ve Sofyalı Bâlî’nin Atvâr-1 Seb'a Risalesi”, Tasavvuf İlmî ve Akademik Araştırma Dergisi, 18, (2007]: 43-63.

Müstakimzâde Süleyman Sadettin. (2000). "Mecelletü'n-Nisâb, Ankara: Tıpkıbasım, Vr. 433. 
Nail Tuman, Tuhfe-i Nâilî, (Haz. M. Tatc1-C. Kurnaz), C. II, Ankara 2001, s. 1149.

Ögke, A. (2001). Ahmed Şemseddin-i Marmaravî, Hayatı-Eserleri-Görüşleri, İstanbul: İnsan Yayınları.

Ömer Fuâdî, Beyân-ı Etvâr-ı Seb 'a, İBB. Atatürk Kitaplığı Nadir Eserler Ktp., Belediye Yazmaları, nr. $981 / 05$, vr. 27b-37a.

Öngören, R. (2011). “Tasavvuf”, TDVİA, XL, 119-126.

Öztürk, A. (2003). "XVI. Yüzyıl Halvetî Siirinde Din ve Tasavvuf”, Yayınlanmamış Doktora Tezi, Ankara Ünv. Sosyal Bilimler Enstitüsü.

(2013). "Halvetîliğin Manzum Etvâr-1 Seb'a Geleneğinde Üç Müellif Bir Eser", Uluslararası Seyyid Yahya Şirvânîve Halvetilik Sempozyumu Bildiri Kitabı, Eskişehir 2013]: 59-68.

Rıhtım, M. (2007). Seyyid Yahya Şirvânî el-Bakuvî, Şifâel Esrâr-Sufiliyin Sırları, Bakü.

Sâdık Vicdânî, Tomar-ı Turuk-ı Aliyye, Tarikatler ve Silsileleri, (Haz. İrfan Gündüz), İstanbul 1995.

Sarığlu, L. A. (2017). "Yedi Tavır Hakkında Yazılmış Bir Risale Tercümesi: Tercüme-i Risâle-i Etvâr-1 Seb'a", Marmara Türkiyat Araştırmaları Dergisi, 4/1, (2017]: 143-158.

Seccâdî, S. C. (2007). Tasavvuf ve İrfân Tarimleri Sözlügü, Çev. Hakkı Uygur, İstanbul:Ensar Neşriyat.

Serin, R. (1984). İslam Tasavvufunda Halvetîlik ve Halvetîler, İstanbul: Petek Yayınları.

Seyyid Şerif Cürcânî, Kitâbu't-Târifât, ts ve bask1 yeri yok, s. 243.

Seyyid İbrahim Efendi, Atvâr-ı Seb 'a, Süleymaniye Ktp., Tâhir Ağa, no: 334, vr. 3.

Seyyid İsmail Bedreddin, Risâle-i Tarîkat, İBB. Atatürk Kitaplığı Nadir Eserler Ktp., Osman Ergin Yazmalar1, nr. 1244/2, vr. 30a-34a.

Seyyid Nizamoğlu Seyfullah (1288). Etvâr-ı Seb'a, İstanbul: Yahya Efendi Matbaası.

Süleyman Fikri. (1338-1345). Antalya Livası Tarihi, I, İstanbul.

Seyyid M. Emin b. Mehmed Kâsım Halvetî, Dîvân-ı Seyyid, Millî Ktp. FB. Nu: 269, vr. 30a-30b.

Selahaddin Abdullah b. Abdülaziz el-Uşşâkî, Etvâr-ı Seb ‘a, Süleymaniye Ktp., Tahir Ağa Tekkesi, nr. 503/2, vr. 10a-13a.

Sünbül Sinan, Risaletü’l-Etvari's-Seb 'a, İBB. Atatürk Kitaplığı Nadir Eserler Ktp., Osman Ergin Yazmaları, nr. 341/02, vr. 23b-24a.

Seyfullah Kâsım b. Nizâmeddin, el-Atvâru's-seb 'a fì tarîki 's-sûfiyye, İstanbul Belediye Ktp., Osman Ergin Yazma, no: 65, vr. 13-30.

Şah Veli b. Muhammed b. Kaya Nâib el-Aksarayî, Risale fi Etvari's-Seb'a, Süleymaniye Ktp., Halet Efendi, nr. 827/8, vr. 56b-68a.

Şengül, F. (2009). Uşşakilerde Etvâr-ı Seb'a, Yüksek Lisans Tezi, Marmara Üniversitesi Sosyal Bilimler Enstitüsü, İstanbul.

Şimşek, A. (2014). "Ümmî Sinanzâde Ced Haşan Efendi ve Kendisine Nisbet Edilen Etvâr-1 Seb'a Risalesi", Şırnak Üniversitesi I. F. Dergisi, 5/10, (2014]: 125-130. 
Şimşek, S. (2012). "Kastamonulu Bir Gülşenîve Şa'bânî Şeyhi La'lî Muhammed Fenâyî'nin Terceme-i Atvâr-1 Seb'a Risalesi", I. Uluslararası Şeyh Şabân-ı Velî Sempozyumu, Kastamonu: 4-6 Mayis 2012: 239-253.

Şengün, N. (2013). Kuloğlu Şeyh İlyas Etvar-ı Seb'a (Nefsin Yedi Mertebesi), Ankara: İlahiyat Yayınları.

Şücaeddin İlyas b. İsa Akhisârî, Risale-i Etvar-ı Seb'a, Süleymaniye Ktp., Halet Efendi, nr. 820/3, vr. 19a-25a.

Şapolyo, E. B. (2006). Mezhepler ve Tarikatler Tarihi, İstanbul: Elif Kitabevi.

Tatc1, M.-Ögke A. (2018). Elmalılı Vâhib Ümmî Halvetî Dîvân-ı İlâhiyât, İstanbul: H Yayınları.

Toprak, M. S. (2013). Cemâli el-Karamânî, Risalef î Etvâr'is-Sülûk (Seyr ü Sülük Makamları), İstanbul: Okuyan Us Yayınları.

Torun, A. (1989). "16. Asır Mutasavvıf Halk Şairlerinden Vâhib Ümmî'nin Hayatı, Mahlası ve Tarikatı", Adımlar, 1 (Ocak 1989), 14-17.

Türer, O. (2003). "Letâif-i Hamse", Türkiye Diyanet Vakfi İslam Ansiklopedisi, Ankara 2003, c. 27, s. 143.

Tosun, N. (2009). “Sır”, Türkiye Diyanet Vakfi İslam Ansiklopedisi, İstanbul, c. 37, s. 115-116.

Uludağ, S. (1991). Tasavvuf Terimleri Sözlüğ̈̈, İstanbul: Marifet Yayınlar1.

Usta, M. (2015). "Tasavvuf Eğitiminde Etvâr-ı Seb’a Metodu”, Yayınlanmamış Doktora Tezi, İstanbul Üniversitesi Sosyal Bilimler Enstitüsü, İstanbul.

Yılmaz, H. K. (2004). Anahatlarıyla Tasavvuf ve Tarikatlar, İstanbul: Ensar Neşriyat.

Yiğitbaşı Ahmed Marmaravî, Risâle-i Tevhîd, Millet Ktp., Ali Emirî, Şer'iyye Bl. Nu: 1343/3, vr. $44 a$.

Yiğitbaşı Ahmed Marmaravî, Silsile-i Ehl-i Tarîkat, Süleymaniye Ktp. Hacı Mahmud Ef. Bl. 2745/1, $4 b$.

Yusuf Sinan b. Ali, Risâletü 'l-Etvâri's-Seb'a, İstanbul Atatürk Kitaplığı Nadir Eserler Kütüphanesi, Osman Ergin Yazmaları, nr. 341/02, vr. 23b, 24a. 